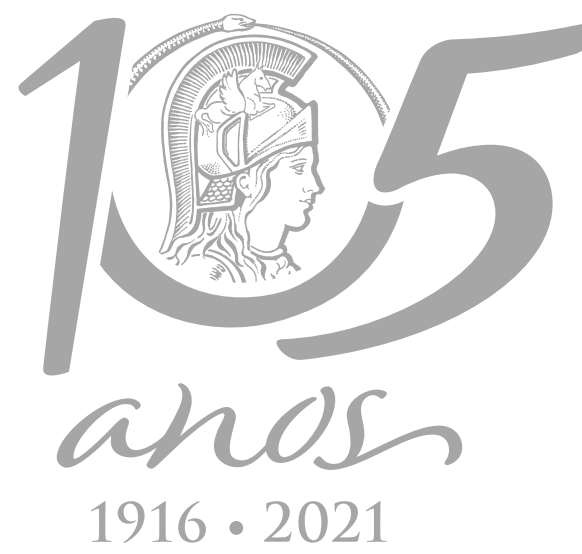

\title{
ECOSYSTEMS
}

\section{Composition and structure of the bryophyte community of Park Savanna in Marajó Island, Pará, Brazil}

\author{
PAULO W.P. GOMES, PRISCILA S. DE MEDEIROS-SARMENTO, RITA DE CÁSSIA P. \\ DOS SANTOS \& ANA CLÁUDIA C. TAVARES-MARTINS
}

\begin{abstract}
Aiming to enrich the knowledge about the flora of savannas, this paper studied the composition and structure of the bryophyte community of Park Savanna areas in Marajó Island - PA. Biological material was collected within $60100-\mathrm{m}^{2}$ plots equally distributed in the dry season of 2016 and the rainy season of 2017 in five Park Savanna areas (SP-I to SP-V). The composition, density, richness and diversity of species and presence of indicator species were compared between the sampled areas and seasons. The species were classified according to the substrates colonized and ecological groups of light tolerance. Significant differences in SP-V indicated that the area was the main factor influencing the composition of bryophytes ( $p$ : 0.0001), with five indicator species. There were also significant differences in density $(p=0.0001168)$ and richness $(p=$ 0.0001317 ) of bryophytes between seasons ( $p$-value $=0.3393 ; p$-value $=0.04065 ; p: 0.1081$ ) There was a predominance of generalist (25 spp.) and corticolous (728 individuals) species, which were widely distributed in the sampled areas. Therefore, the structure of the bryophyte communities was not influenced by seasonality, and this indicates that these plants are adapted to the environmental conditions.
\end{abstract}

Key words: amazonian savannas, bryoflora, ecology, seasonal precipitation.

\section{INTRODUCTION}

Brazilian savannas (Cerrado) are predominantly distributed in the Central Plateau region, forming the second largest neotropical biome and considered one of the biodiversity hotspots for conservation priorities (Myers et al. 2000, Rios et al. 2016). Savannas also occur within the Amazon biome (Amazonian savannas) formed by disjoint patches that altogether cover an area of about $267 \mathrm{~km}^{2}$ (Carvalho \& Mustin 2017). They reach the east portion of the Marajó island and other spots distributed in the states of Amapá, Amazonas, Pará and Roraima (Prance 1996, Rossetti et al. 2007), and are characterized by the predominance of grasses and a variable density of trees and shrubs (Silva \& Oliveira 2018).

Savannas are ecosystems influenced by high light intensity and drought events, which increase the chances of spread of fires (Hoffmann et al. 2012). Microclimatic conditions such as luminosity, temperature, humidity, and $\mathrm{pH}$ act as environmental filters that can determine the structure of bryophyte communities (Weibull \& Rydin 2005, Bello et al. 2010, Smith \& Stark 2014, Santos et al. 2014). Desiccation tolerant bryophytes are common in savannas (Visnadi \& Vital 1989), since only the best adapted species settle in these areas (Kürschner 2004, Kürschner \& Parolly 2005, Pardow \& Lakatos 2013). 
The composition of bryophytes in tropical forest is influenced by microhabitat variability along the different height zones of host trees (Holz et al. 2002, Gosselin et al. 2017). The relationship of bryophytes with the microhabitat can be explained by structural and chemical characteristics of the substrate and exposure to light, wind and precipitation (Hespanhol et al. 2011, Gosselin et al. 2017).

The distribution pattern of plant communities in Amazonian savannas is still little known (Cavalcante et al. 2014) and more studies are needed to promote the conservation of their biodiversity, which has a high rate of endemic species (Strassburg et al. 2017). Many of these species in Amazonian savannas are threatened with extinction due to constant clearance of forest areas to meet agriculture and livestock demands associated with population growth (Plotkin \& Riding 2011, Carvalho \& Mustin 2017).

In view of the heterogeneity and social value of their different phytophysiognomies of savannas (Plotkin \& Riding 2011, Fearnside 2015), their conservation requires investments in research for the implementation of new Environmental Protection Areas (Mustin et al. 2017). Knowledge of the ecology of bryophytes can be useful because these plants can serve as models for management and conservation strategies of these savannas. Since, some studies simulating environmental changes and micro fossil analyses have suggested that climate change will strongly affect both the abundance and composition of the briophyte communities (Dorrepaal et al. 2004, Walker et al. 2006, Lang et al. 2009, Elmendorf et al. 2012), which in turn affects the structure and functioning of the ecosystem where bryophytes and vascular plants cooccur (He et al. 2016).

The objective of the present study was to evaluate the composition and structure of bryophyte communities in Park Savanna areas in Marajó Island, state of Pará.

\section{MATERIALS AND METHODS}

\section{Study area}

The study area corresponded to five savannas classified as belonging to the Park Savanna (SP) phytophysiognomy (Rossetti et al. 2007, IBGE 2012), located in the east side of the Marajó Island, state of Pará. Four Park Savanna areas are located in the municipality of Salvaterra; of these, SP-I (00 $47^{\circ} 47.5^{\prime \prime} \mathrm{S}$ and $\left.48^{\circ} 32^{\prime} 39.7^{\prime \prime} \mathrm{W}\right)$ and SP-IV (00 52' 24.8' S and $\left.48^{\circ} 35^{\prime} 07.7^{\prime \prime} \mathrm{W}\right)$ can be easily seen from the Camará-Salvaterra road margins, and SP-II (00 51' 44,4" S and $48^{\circ}$ $\left.31^{\prime} 45,0^{\prime \prime} \mathrm{W}\right)$ and SP-III (00 51' 09,4' $\mathrm{S}$ and $48^{\circ}$ $\left.31^{\prime} 55,9^{\prime \prime} \mathrm{W}\right)$ from the Salvaterra-Joanes road. The SP-V (00 $54^{\prime} 32.3^{\prime \prime} \mathrm{S}$ and $\left.48^{\circ} 40^{\prime} 06.9^{\prime \prime} \mathrm{W}\right)$ is located at the margins of the PA-154 road, in the municipality of Cachoeira do Arari. The peculiar characteristics of the current physiognomic aspect of these savannas are described in Table I. The climate is humid equatorial with average annual temperature of $28^{\circ} \mathrm{C}$ and precipitation all the year round. The months with less precipitation in the period studied were August through October (average of $19 \mathrm{~mm}$ ) and the ones with more precipitation were January through April (average of $504 \mathrm{~mm}$ ). This information was obtained from the database of the National Institute of Meteorology (http://www.inmet.gov. $\mathrm{br} /$ portal/index.php? $\mathrm{r}=$ home2 $/$ index) .

\section{Sampling, collection and taxonomic identification}

Sixty $100 \mathrm{~m}^{2}$ (10 m x $\left.10 \mathrm{~m}\right)$ plots were established and usual sampling techniques for bryophytes were adopted (Vanderpoorten et al. 2010). Thirty plots were equally distributed in the five savannas during the dry season of 2016, and 30 during the rainy season in 2017. Field 
Table I. Phytophysiognomy characterization of the five Park Savanna areas in Marajó Island, Pará, Brazil.

\begin{tabular}{|c|c|}
\hline $\begin{array}{c}\text { Park } \\
\text { Savanna }\end{array}$ & Description of the area \\
\hline SP-I & $\begin{array}{c}\text { Prevalence of Poaceae and Cyperaceae grasses, forming large open fields affected by heavy } \\
\text { flooding during the rainy season due to proximity to mangrove water courses; less dense } \\
\text { tree stratum formed by Astrocaryum vulgare Mart., Attalea maripa (Aubl.) Mart., Byrsonima } \\
\text { chrysophylla Kunth, and Curatella americana L. }\end{array}$ \\
\hline SP-II & $\begin{array}{l}\text { Vegetation similar to the cerrado of the Central Plateau, with well drained soils and absence of } \\
\text { floods; prevalence of Poaceae and Cyperaceae grasses, and tree stratum with sparse and less } \\
\text { dense vegetation mainly composed of Hancornia speciosa Gom. and C. americana, in addition } \\
\text { to A. vulgare, B. chrysophylla, Platonia insignis Mart., and Salvertia convallariaeodora A. St.-Hil. }\end{array}$ \\
\hline SP-III & $\begin{array}{c}\text { Vegetation similar to the cerrado of the Central Plateau, with well drained soils and absence of } \\
\text { floods; prevalence of Poaceae and Cyperaceae grasses, and tree stratum with sparse and less } \\
\text { dense vegetation mainly composed of H. speciosa and C. americana, in addition to A. vulgare, } \\
\text { B. chrysophylla, P. insignis, and S. convallariaeodora. }\end{array}$ \\
\hline SP-IV & $\begin{array}{c}\text { Vegetation similar to the cerrado of the Central Plateau, presence of floods due to overflow of } \\
\text { creeks in the rainy period; predominance of Poaceae and Cyperaceae grasses, and vegetation } \\
\text { mainly composed of C. americana and S. convallariaeodora, in addition to } \mathrm{H} \text {. speciosa and B. } \\
\text { chrysophylla. }\end{array}$ \\
\hline SP-V & $\begin{array}{c}\text { Denser vegetation in relation to the previous ones and similar to the cerrado of the Central } \\
\text { Plateau, with well drained soils and absence of floods; predominance of Poaceae and } \\
\text { Cyperaceae grasses; vegetation mainly composed of C. americana and B. chrysophylla, besides } \\
\text { P. insignis, S. convallariaeodora and A. vulgare. }\end{array}$ \\
\hline
\end{tabular}

collection and preservation of botanical material followed the methodology of Glime (2017). The bryophytes were collected in wooden paper bags and a single bag corresponded to a sample, which in this study was adopted the theme occurrence to represent the species found in each sample. Within each plot, it had at least five living trees, where the bryophytes were collected from the base to the crown of host trees (accessed through climbing techniques), but without dividing crown into zones. In some plots, bryophytes were also collected in decomposing trunks, soil, and termite mounds. Specialized literature (Buck 2003, Florschütz-De Waard 1996, Gradstein \& Ilkiu-Borges 2009) was used for identification and the classification system adopted was the one of Crandall-Stotler et al. (2009) for liverworts and Goffinet et al. (2009) for mosses. The database of the Flora do Brasil 2020 under construction (Costa \& Peralta 2015) was used to confirm scientific names. The botanical material was incorporated in the Prof. Dr. Marlene Freitas da Silva (MFS) Herbarium of the State University of Pará.

\section{Data analysis}

Species accumulation curves were generated in the iNEXT software (Hsieh et al. 2013), using an individual based data matrix of the bryophyte communities to evaluate sampling sufficiency.

The composition of the community was compared between the two seasons and 
between areas through PERMANOVAs based on a Bray-Curtis distance matrix (Zar 2010) and summarized through a Principal Component Analysis (PCA). Indicator species analysis (IndVal), carried out in the R software (Dufrêne \& Legendre 1997), was used to identify whether some of the species could indicate differences in composition. Mean values of density, richness and diversity per plot were adopted to analyze the structure of the community. The Student's t-test (or the non-parametric equivalent test) was used to compare the density and richness between seasons, and the Kruskal-Wallis ranksum test (Dunn 1964) was used for pairwise multiple comparisons between areas. Twoway Analysis of Variance (ANOVA) was used to compare the density and richness of bryophytes between different areas in the two seasons (Ayres et al. 2007). The interaction plot (interaction plot) was used to facilitate the interpretation of the boxplot generated in the two-way ANOVA. The Fisher's alpha diversity index (Magurran 1988) was used to analyze the variations of species richness and abundance between seasons and areas sampled, using the "vegan" package (Oksanen et al. 2007) in the R software v. 3.1.3 (R Development Core Team 2018).

For the study of species distribution, the species were classified according to the ecological groups of light tolerance, namely, sun specialists, shade specialists, and generalists. This classification was based on the works of Richards (1984), Gradstein et al. (2001), Pantoja et al. (2015), and Fagundes et al. (2016). To verify whether there were specific communities in the different areas or if there was a single community of generalist species throughout the savannas, the density and richness of generalist species was analyzed by multiple comparisons with the Kruskal-Wallis rank-sum test (Dunn 1964). The species were classified as to substrate colonized, based on Robbins (1952) with adaptations, and the absolute frequency of the rare species was classified according to the number of occurrences $(>1<5)$, based on Silva \& Pôrto (2007).

\section{RESULTS}

\section{Species accumulation curves}

Less than $25 \%$ of the species were shared between the five areas, which include four taxa of mosses - Calymperes erosum Müll. Hal., Calymperes palisotii Schwägr., Microcalpe subsimplex (Hedw.) W.R. Buck, and Octoblepharum albidum Hedw. - and three of liverworts - Cheilolejeunea comans (Spruce) R.M.Schust., Cheilolejeunea oncophylla (Aongström) Grolle \& E.Reiner, and Cheilolejeunea rigidula (Mont.) R.M.Schust.

Rare species represented about 63\% (26) of the sample; 11 species were represented by one occurrence each and five species by two occurrences each. The presence of these levels of rarity contributed to the non-stabilization of accumulation curves, as demonstrated by the fact that there was no saturation of species in the five sampled areas and seasons (Figure $1 a-d)$.

\section{Floristic composition}

Three hundred and sixteen samples of bryophytes were analyzed, resulting in 41 species with 820 occurrences. Liverworts had a higher richness, with Lejeuneaceae (24 spp., 306 occurrences) followed by Frullaniaceae (two spp., four occurrences). Mosses (15 spp.) were more abundant, with 510 occurrences, of which 383 belonged to Calymperaceae (five spp.), especially Calymperes palisotii Schwägr. (108) and Octoblepharum albidum Hedw. (206), which were widely distributed in the studied areas (Table II). There was a predominance of acrocarpous over pleurocarpous mosses, with $78 \%$ (11) of the species distributed in the families 

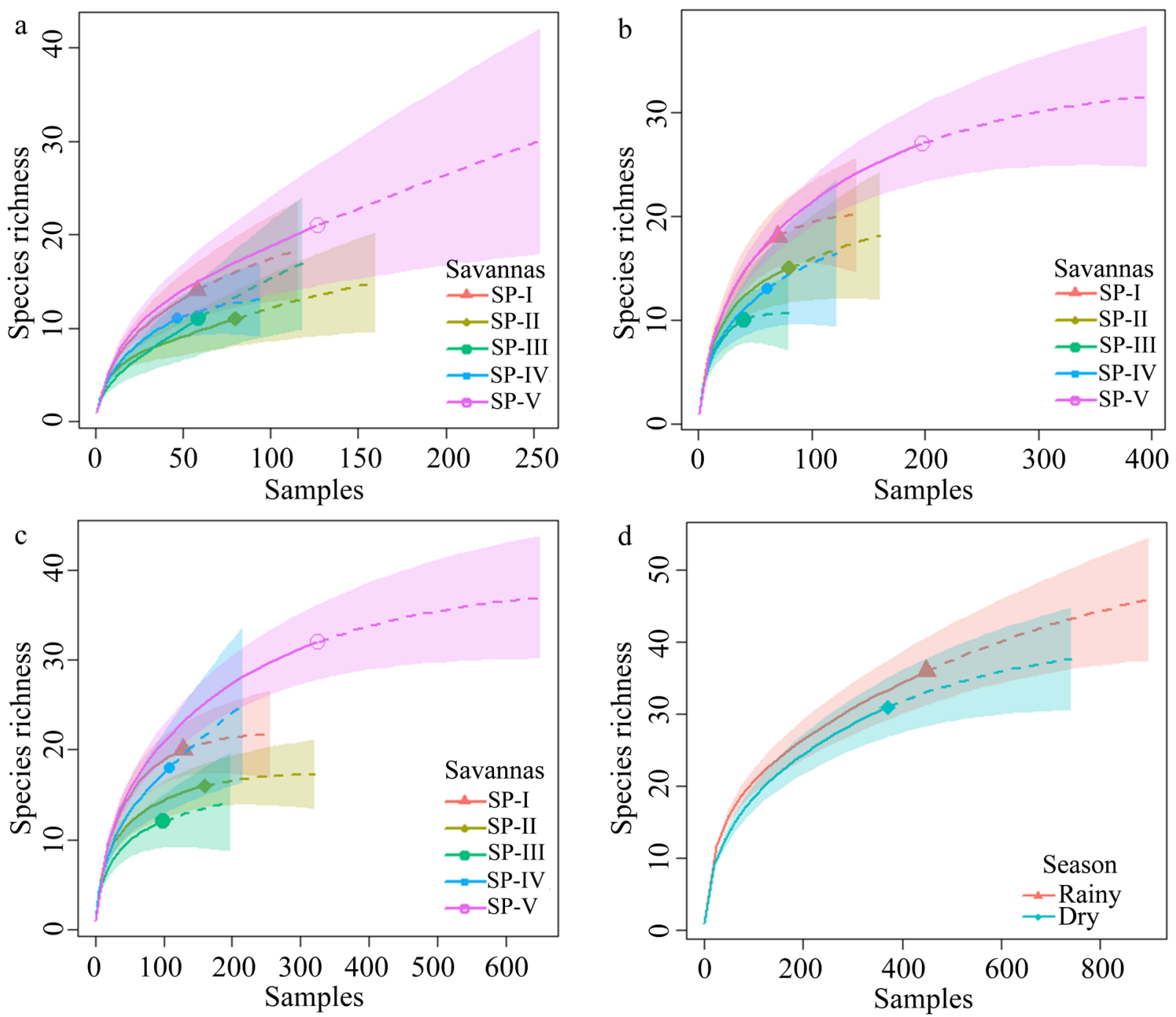

Figure 1. Species accumulation curves in the sampled Park Savanna areas and seasons, Marajó Island, Pará. (a) all areas per dry season; (b) all areas per rainy season; (c) all areas; (d) all areas per rainy and dry season.

Bryaceae, Calymperaceae, Fissidentaceae, Leucobryaceae, and Orthotrichaceae.

\section{Species composition}

The species composition of SP-V differed significantly from other areas (Pseudo- $F=4.111$; $\mathrm{p}$-value $=0.0001)$ (Figure 2a), and there were five indicator species: Acrolejeunea emergens (Mitt.) Steph., Acrolejeunea torulosa (Lehm \& Lindenb.) Schiffn., Microlejeunea epiphylla Bischl., Fissidens guianensis Mont., and Frullania exilis Taylor. SP-I was significantly different only from SP-II and SP-III ( $p$-value $=0.0234 ; p$-value
= 0.0069), with Campylopus surinamensis Müll. Hal. and Cheilolejeunea trifaria (Reinw. et al.) Mizut. as indicator species. The sets of SP-I and SP-IV presented similar bryoflora in both seasons, as observed in the large overlap of these groups (Figure 2a).

No significant variation was observed in species composition between wet and dry season (Pseudo- $F=1.7059 ; p$-value $=0.1081$ ) due to the large overlap of groups (Figure 2b). The first two dimensions of the PCA explained $59.8 \%$ of the variance in the data set; the first 
Table II. List of bryophytes of the five Park Savanna areas in Marajó Island, Pará.

\begin{tabular}{|c|c|c|c|c|c|c|c|c|c|c|c|c|c|}
\hline \multirow{2}{*}{ Bryophyte } & \multicolumn{5}{|c|}{ Park Savanna area } & \multicolumn{2}{|c|}{ Season } & \multirow{2}{*}{ EG } & \multicolumn{4}{|c|}{ Substrates } & \multirow{2}{*}{ Voucher } \\
\hline & I & II & III & IV & V & $\mathbf{R}$ & D & & Co & $\mathbf{E}$ & $\mathbf{T}$ & TM & \\
\hline \multicolumn{14}{|l|}{ Bryophyta } \\
\hline \multicolumn{14}{|l|}{ Bryaceae } \\
\hline Bryum coronatum Schwägr. & & & 1 & 1 & 2 & 1 & 3 & Gen & 3 & & 1 & & MFS007628 \\
\hline \multicolumn{14}{|l|}{ Calymperaceae } \\
\hline Calymperes erosum Müll. Hal. & 15 & 8 & 4 & 6 & 17 & 35 & 15 & Gen & 46 & 4 & & & MFS007629 \\
\hline Calymperes palisotii Schwägr. & 20 & 24 & 11 & 23 & 30 & 57 & 51 & Gen & 90 & 15 & 1 & 2 & MFS007630 \\
\hline Octoblepharum albidum Hedw. & 33 & 42 & 36 & 33 & 62 & 97 & 109 & Gen & 197 & 7 & 2 & & MFS007631 \\
\hline Syrrhopodon ligulatus Mont. & & 7 & & 6 & 5 & 16 & 2 & Gen & 17 & 1 & & & MFS007632 \\
\hline Syrrhopodon prolifer Schwägr. & & & & 1 & & 1 & & Gen & 1 & & & & MFS007633 \\
\hline \multicolumn{14}{|l|}{ Fissidentaceae } \\
\hline Fissidens angustifolius Sull. & & & & & 2 & & 2 & Gen & 2 & & & & MFS008750 \\
\hline Fissidens guianensis Mont. & & & & & 3 & 2 & 1 & Gen & 1 & & 1 & 1 & MFS008744 \\
\hline Fissidens prionodes Mont. & 1 & & & 1 & 1 & 1 & 2 & Gen & & & 3 & & MFS007634 \\
\hline \multicolumn{14}{|l|}{ Leucobryaceae } \\
\hline $\begin{array}{l}\text { Campylopus surinamensis Müll. } \\
\text { Hal. }\end{array}$ & 12 & & & 4 & & 7 & 9 & Sun & 8 & & 8 & & MFS007635 \\
\hline \multicolumn{14}{|l|}{ Orthotrichaceae } \\
\hline $\begin{array}{l}\text { Groutiella tomentosa (Hornsch.) } \\
\text { Wijk \& Margad. }\end{array}$ & & & & & 1 & 1 & & Gen & 1 & & & & MFS008742 \\
\hline \multicolumn{14}{|l|}{ Sematophyllaceae } \\
\hline $\begin{array}{c}\text { Brittonodoxa subpinnata (Brid.) } \\
\text { W.R.Buck }\end{array}$ & & & & & 1 & 1 & & Gen & 1 & & & & MFS008741 \\
\hline $\begin{array}{c}\text { Microcalpe subsimplex (Hedw.) } \\
\text { W.R. Buck }\end{array}$ & 5 & 25 & 27 & 11 & 26 & 38 & 56 & Gen & 89 & 5 & & & MFS007636 \\
\hline $\begin{array}{l}\text { Sematophyllum adnatum } \\
\text { (Michx.) Brid. }\end{array}$ & & & & & 2 & 2 & & Gen & 2 & & & & MFS008747 \\
\hline $\begin{array}{l}\text { Trichosteleum papillosum } \\
\text { (Hornsch.) A.Jaeger }\end{array}$ & & & & & 1 & 1 & & Gen & & 1 & & & MFS008745 \\
\hline \multicolumn{14}{|l|}{ Marchantiophyta } \\
\hline \multicolumn{14}{|l|}{ Frullaniaceae } \\
\hline Frullania exilis Taylor & & & & & 3 & 2 & 1 & Sun & 3 & & & & MFS008751 \\
\hline Frullania gibbosa Nees & & & & & 1 & 1 & & Sun & 1 & & & & MFS008747 \\
\hline \multicolumn{14}{|l|}{ Lejeuneaceae } \\
\hline $\begin{array}{c}\text { Acrolejeunea emergens (Mitt.) } \\
\text { Steph. }\end{array}$ & 2 & & & 2 & 16 & 11 & 9 & Sun & 17 & 3 & & & MFS007637 \\
\hline
\end{tabular}


Table II. Continuation

\begin{tabular}{|c|c|c|c|c|c|c|c|c|c|c|c|c|c|}
\hline \multirow{2}{*}{ Bryophyte } & \multicolumn{5}{|c|}{ Park Savanna area } & \multicolumn{2}{|c|}{ Season } & \multirow{2}{*}{ EG } & \multicolumn{4}{|c|}{ Substrates } & \multirow{2}{*}{ Voucher } \\
\hline & $\mathbf{I}$ & II & III & IV & v & $\mathbf{R}$ & D & & Co & $\mathbf{E}$ & $\mathbf{T}$ & TM & \\
\hline $\begin{array}{c}\text { Acrolejeunea torulosa (Lehm. \& } \\
\text { Lindenb.) Schiffn. }\end{array}$ & 4 & & 1 & 8 & 53 & 41 & 25 & Sun & 57 & 8 & & 1 & MFS007638 \\
\hline $\begin{array}{l}\text { Archilejeunea fuscescens (Hampe } \\
\text { ex Lehm.) Fulford. }\end{array}$ & 2 & & & & 1 & 1 & 2 & Gen & 3 & & & & MFS007639 \\
\hline $\begin{array}{c}\text { Cheilolejeunea aneogyna } \\
\text { (Spruce) A. Evans }\end{array}$ & & & & 1 & & 1 & & Gen & 1 & & & & MFS007640 \\
\hline $\begin{array}{c}\text { Cheilolejeunea clausa (Nees \& } \\
\text { Mont.) R.M.Schust. }\end{array}$ & & 1 & & & & 1 & & Sun & 1 & & & & MFS007641 \\
\hline $\begin{array}{c}\text { Cheilolejeunea comans (Spruce) } \\
\text { R.M.Schust. }\end{array}$ & 4 & 7 & 1 & 3 & 2 & 10 & 7 & Gen & 15 & 1 & & 1 & MFS007642 \\
\hline $\begin{array}{c}\text { Cheilolejeunea discoidea (Lehm. } \\
\text { \& Lindenb.) Kachroo \& } \\
\text { R.M.Schust. }\end{array}$ & & 1 & & & & & 1 & Gen & 1 & & & & MFS007643 \\
\hline $\begin{array}{l}\text { Cheilolejeunea holostipa } \\
\text { (Spruce) Grolle \& R.-L.Zhu }\end{array}$ & & & & & 1 & 1 & & Gen & 1 & & & & MFS008740 \\
\hline $\begin{array}{l}\text { Cheilolejeunea oncophylla } \\
\text { (Aongström) Grolle \& E.Reiner }\end{array}$ & 10 & 20 & 4 & 4 & 39 & 42 & 35 & Gen & 69 & 7 & & 1 & MFS007644 \\
\hline $\begin{array}{c}\text { Cheilolejeunea rigidula (Mont.) } \\
\text { R.M.Schust. }\end{array}$ & 2 & 10 & 3 & 1 & 10 & 12 & 14 & Gen & 22 & 4 & & & MFS007645 \\
\hline $\begin{array}{c}\text { Cheilolejeunea trifaria (Reinw. et } \\
\text { al.) Mizut. }\end{array}$ & 3 & & & & & 1 & 2 & Gen & 2 & 1 & & & MFS007646 \\
\hline Drepanolejeunea fragilis Bischl. & & & & & 3 & & 3 & Gen & 2 & 1 & & & MFS008748 \\
\hline $\begin{array}{c}\text { Frullanoides corticalis (Lehm. \& } \\
\text { Lindenb.) Slageren }\end{array}$ & 2 & & & & & 1 & 1 & Sun & 2 & & & & MFS007647 \\
\hline Lejeunea flava (Sw.) Nees & & & & 1 & 1 & 1 & 1 & Gen & 2 & & & & MFS007648 \\
\hline $\begin{array}{c}\text { Lejeunea laetevirens Nees \& } \\
\text { Mont. }\end{array}$ & 1 & 2 & 6 & & 8 & 11 & 6 & Gen & 15 & 2 & & & MFS007649 \\
\hline $\begin{array}{c}\text { Lopholejeunea subfusca (Nees) } \\
\text { Schiffn. }\end{array}$ & & & & & 2 & 2 & & Sun & 2 & & & & MFS008739 \\
\hline $\begin{array}{c}\text { Microlejeunea bullata (Taylor) } \\
\text { Steph. }\end{array}$ & & & & & 1 & & 1 & Gen & & 1 & & & MFS008749 \\
\hline Microlejeunea epiphylla Bischl. & 3 & 5 & 2 & & 17 & 21 & 6 & Gen & 23 & 4 & & & MFS007650 \\
\hline $\begin{array}{c}\text { Microlejeunea globosa (Spruce) } \\
\text { Steph. }\end{array}$ & & & & 1 & & & 1 & Gen & 1 & & & & MFS007651 \\
\hline
\end{tabular}


Table II. Continuation

\begin{tabular}{|c|c|c|c|c|c|c|c|c|c|c|c|c|c|}
\hline \multirow{2}{*}{ Bryophyte } & \multicolumn{5}{|c|}{ Park Savanna area } & \multicolumn{2}{|c|}{ Season } & \multirow{2}{*}{ EG } & \multicolumn{4}{|c|}{ Substrates } & \multirow{2}{*}{ Voucher } \\
\hline & $\mathbf{I}$ & II & III & IV & v & $\mathbf{R}$ & D & & Co & E & $\mathbf{T}$ & TM & \\
\hline Microlejeunea subulistipa Steph. & 3 & 2 & & & 3 & 7 & 1 & Gen & 7 & & & 1 & MFS007652 \\
\hline $\begin{array}{c}\text { Pycnolejeunea contigua (Nees) } \\
\text { Grolle }\end{array}$ & 1 & & & & 4 & 4 & 1 & Sun & 3 & 2 & & & MFS007653 \\
\hline $\begin{array}{l}\text { Pycnolejeunea macroloba (Nees } \\
\text { \& Mont.) Schiffn. }\end{array}$ & 1 & 2 & & 1 & & 3 & 1 & Sun & 4 & & & & MFS007654 \\
\hline Pycnolejeunea papillosa X.-L. He & 4 & 3 & 3 & & 2 & 10 & 2 & Sun & 10 & 2 & & & MFS007655 \\
\hline Pycnolejeunea sp. & & 2 & & & 4 & 5 & 1 & * & 6 & & & & MFS008743 \\
\hline Total & 128 & 161 & 99 & 108 & 324 & 449 & 371 & & 728 & 69 & 16 & 7 & \\
\hline
\end{tabular}

I - Vila de Jubim (SP-I); II - Vila de Joanes (SP-II); III - Vila de Água Boa (SP-III); Vila União (SP-IV); Vila de Camará (SP-V); R - Rainy season; D - Dry season; EG - Ecological group; Gen - Generalist; Sun - Sun specialist; *Not determined; Co - Corticolous; E Epyxilic; T - Terricolous; TM - Termite Mound.

dimension accounted for $39.7 \%$, and the second for $20.1 \%$.

\section{Density, richness and diversity}

SP-V presented a significantly different density (Kruskal-Wallis $=23,176 ;$-value $=0.0001168)$ (Figure 3a) and richness (Kruskal-Wallis = 22,914; $p$-value $=0.0001317)$ in relation to the other sampled areas (Figure 3b).

Seasonality did not influence the density of bryophytes ( $W=515$; $p$-value $=0.3393$ ) (Figure 3c), but richness was significantly lower in the dry season $(t=2.0939$; $p$-value $=0.04065$ ) (Figure $3 d$ ). The number of species in the dry season was about $86 \%$ of the species recorded during the rainy season (31 against 36 ). Most species (26 spp.) occurred in both seasons and less than one quarter was exclusive of the dry (five spp.) or rainy (10 spp.) season.

The interaction plots indicated that there were variations in the number of occurrences and species among the savannas in the rainy and dry season, but seasonality did not significantly affect the mean density (Figure $4 \mathrm{a}$ ) and richness (Figure 5b). The diagrams showed that the area was the main factor influencing the density
(Figure $4 \mathrm{~b}$ and $\mathrm{c}$ ) and richness (Figure $5 \mathrm{~b}$ and c) of bryophytes in the savannas sampled, with SP-V standing out among the others.

Fisher's alpha indices were consistent with changes in species richness and abundance between sampled areas and seasons, with a pattern of increasing diversity, richness and abundance indices, as well as with species accumulation curves, with higher values for SP-V (8.80) in both seasons (Table III).

\section{Ecological groups}

More than half of the species were generalist (30 spp.), found throughout the height of host trees. They were followed by the sun specialists (11 spp.). There was a significant variation in the density of generalist species between the sampled areas (Kruskal-Wallis $=30.54 ;$ p-value $=0.0005$ ) (Figure 6a), with significant difference between areas $I$ and $\|(p$-value $=0.001)$ and III $(p$-value $=0.006)$, between areas $\|$ and $V(p$-value $=0.005)$, between areas $I I I$ and $V$ $(p$-value $=0.005)$, and between areas IV and $V$ ( $p$-value $=0.0008)$. The richness of the generalist species also varied between the sampled areas (Kruskal-Wallis $=25.019 ; \mathrm{p}$-value $=0.0005)$ (Figure 

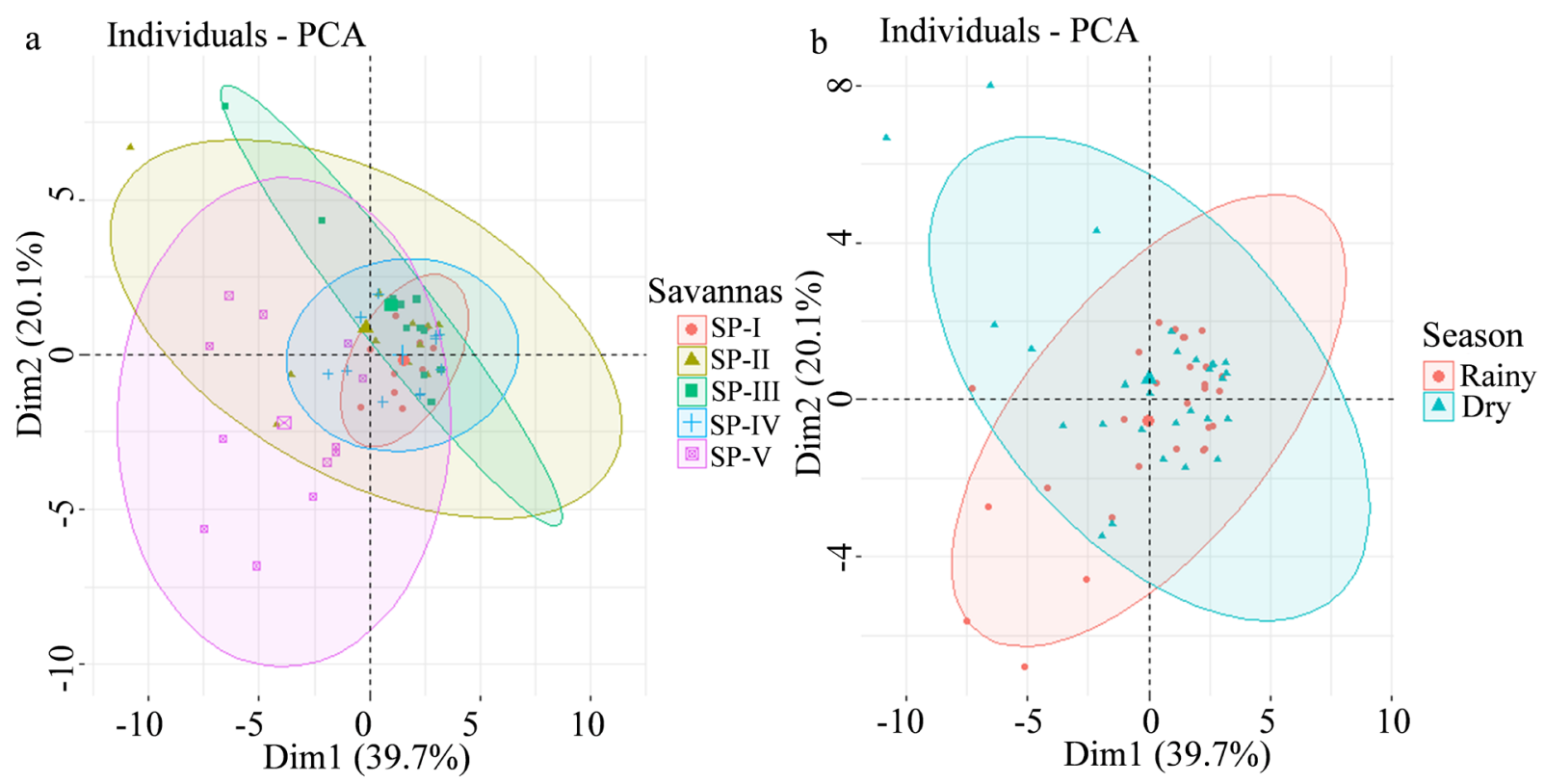

Figure 2. Principal Component Analysis of bryophytes of the Marajó Island, Pará. (a) Sampled savanna áreas; (b) Seasons.

6b), with significant differences between area I and II (p-value $=0.001)$ and III (p-value $=0.009)$, between areas $I I$ and $V(p$-value $<0.005)$, and between areas IV and V ( $p$-value $=0.005)$.

\section{Distribution of bryophytes by substrate}

The corticolous species were predominant with 88.7\% (728) of occurrences, observed along the host trees. Dead trunks were the second most colonized substrates, with $8.4 \%$ (69) of occurrences of the epyxilic species, followed by termite mounds $(1.9 \%, 16)$ and soil $(0.8 \%$, seven).

Rare species (26 spp.) were mostly established in live substrates, of which 84\% (22) were in live substrate samples, and of these, 17 species occurred on SP-V and with low values in SP-I and SP-IV (six Spp.), SP-II (three spp.) and SP-III (one sp.). Of the 32 species recorded in SP-V, 29 (270 occurrences) were found on live trunks and 16 on dead branches; only the taxa Microlejeunea bullata (Taylor) Steph. and Trichosteleum papillosum (Hornsch.) A. Jaeger occurred exclusively on dead branches, while the others occurred synchronously in the two substrates.

\section{DISCUSSION}

\section{Accumulation curves}

The non-stabilization of accumulation curves in floristic studies in tropical forests is common due to the overrepresentation of rare species. In the case of bryophytes in the Amazon, the predominance of rare species has been cited for the Caxiuanã National Forest in Pará, in non-flooded areas and floodplains, "campinas", "campinaranas", and savanna vegetation (Alvarenga \& Lisboa 2009). Schilling \& Batista (2008) pointed out that the widespread distribution of rare species is common in tropical forests and contributes to an marked growing trend in species accumulation curves.

Highly represented rare species in certain sites, such as in the savannas studied, are considered by Myers et al. (2000) to represent a 


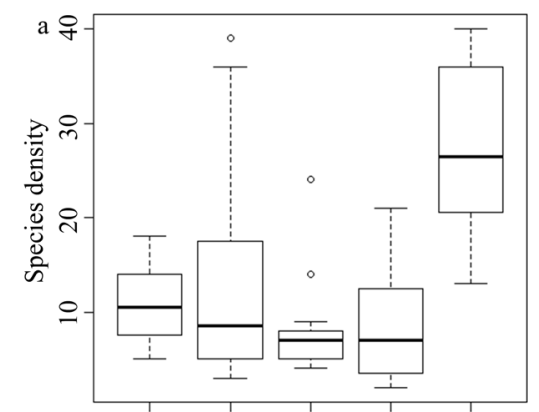

SP-I SP-II SP-III SP-IV SP-V Savannas

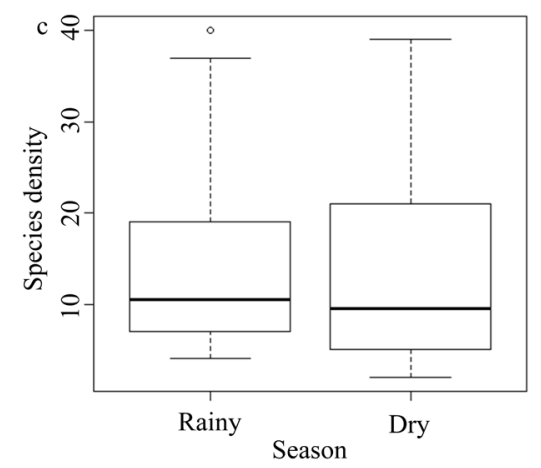

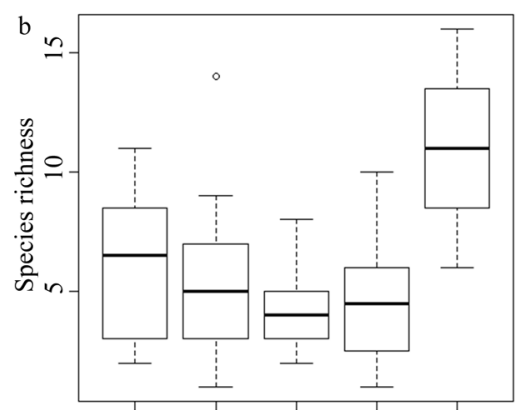

SP-I SP-II SP-III SP-IV SP-V Savannas

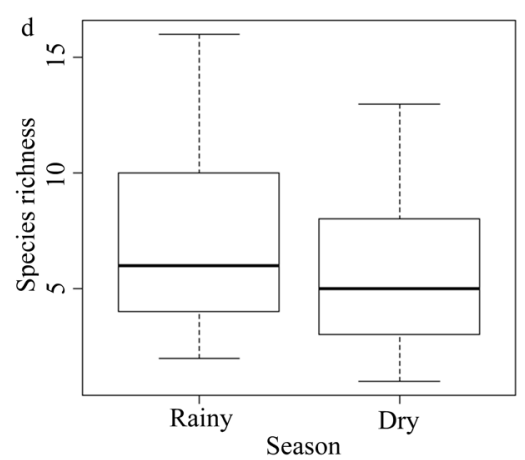

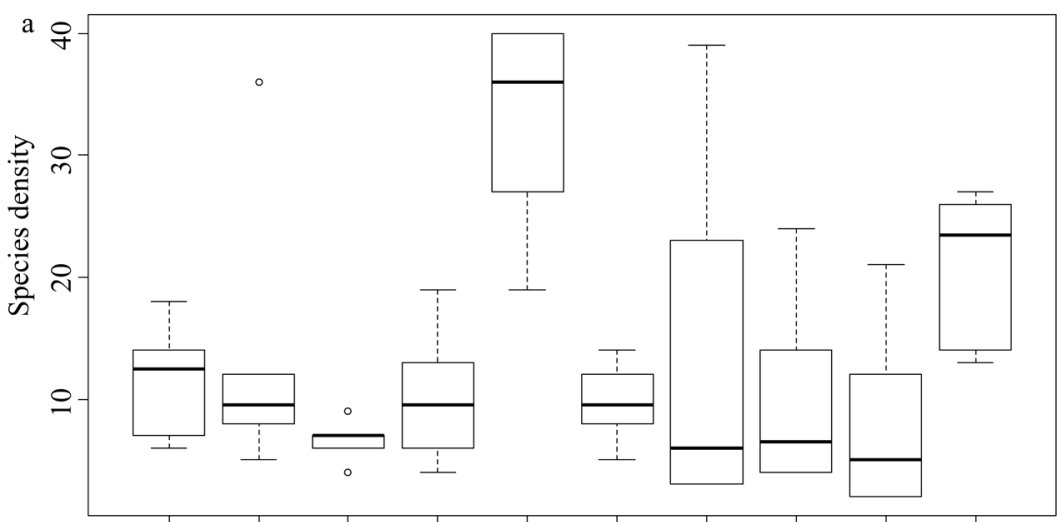

SP-I SP-II SP-III SP-IV SP-V SP-I SP-II SP-III SP-IV SP-V Rainy season

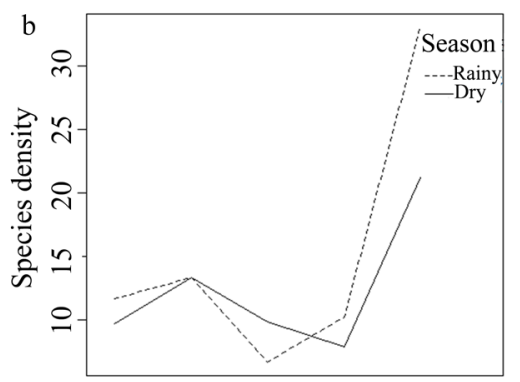

SP-I SP-II SP-III SP-IV SP-V Savannas
Dry season

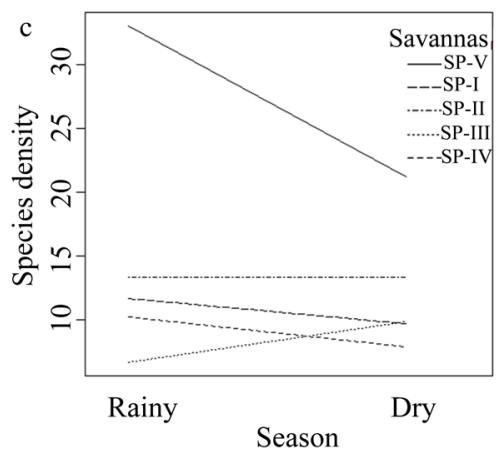

Figure 3. Mean density and richness of species per plot in the studied areas and seasons in Marajó island, Pará. (a) Mean density in the five Park Savanna areas; (b) Mean richness in the five Park Savanna areas; (c) Mean density in the two seasons; (d) Mean richness in the two seasons.
Figure 4. (a) Mean density of bryophytes in the sampled savannas per season; (b) Interaction plot between sampled areas and seasons on mean density of bryophytes; (c) Interaction plot between seasons and sampled areas on mean density of bryophytes. 


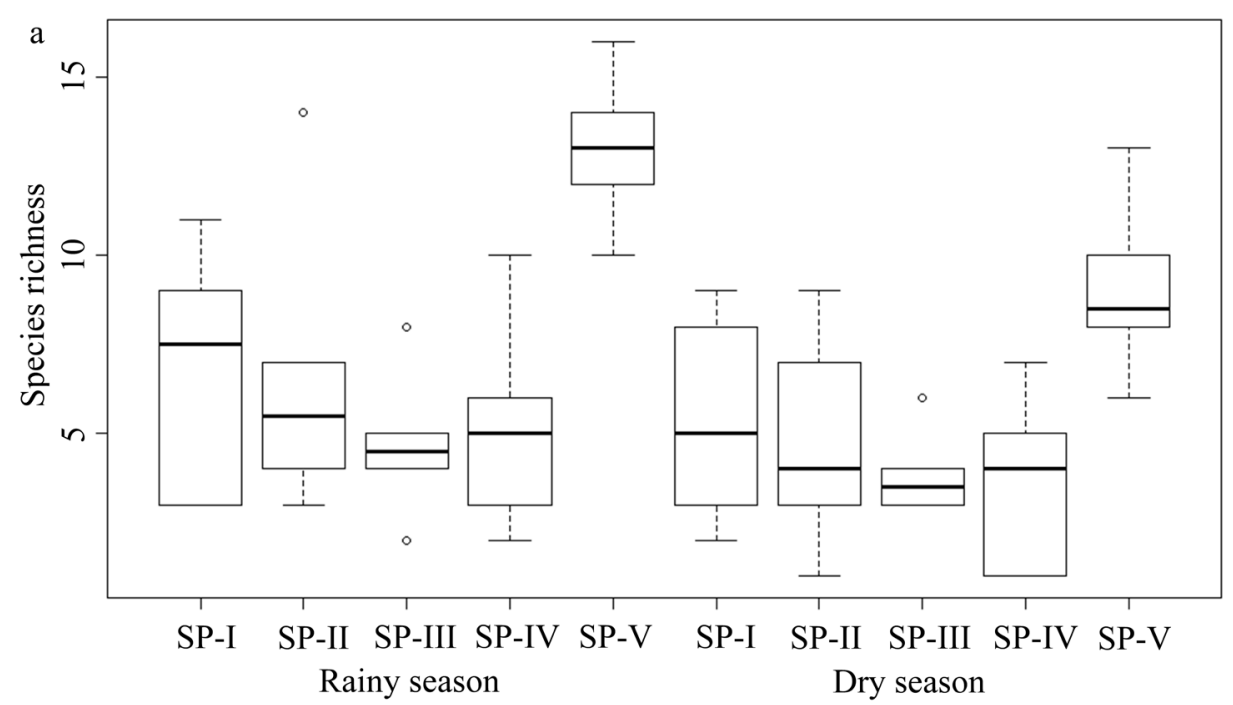

Figure 5. (a) Mean richness of bryophytes in the sampled savannas per season; (b) Interaction plot between sampled areas and seasons on mean richness of bryophytes; (c) Interaction plot between seasons and sampled areas on mean richness of bryophytes.
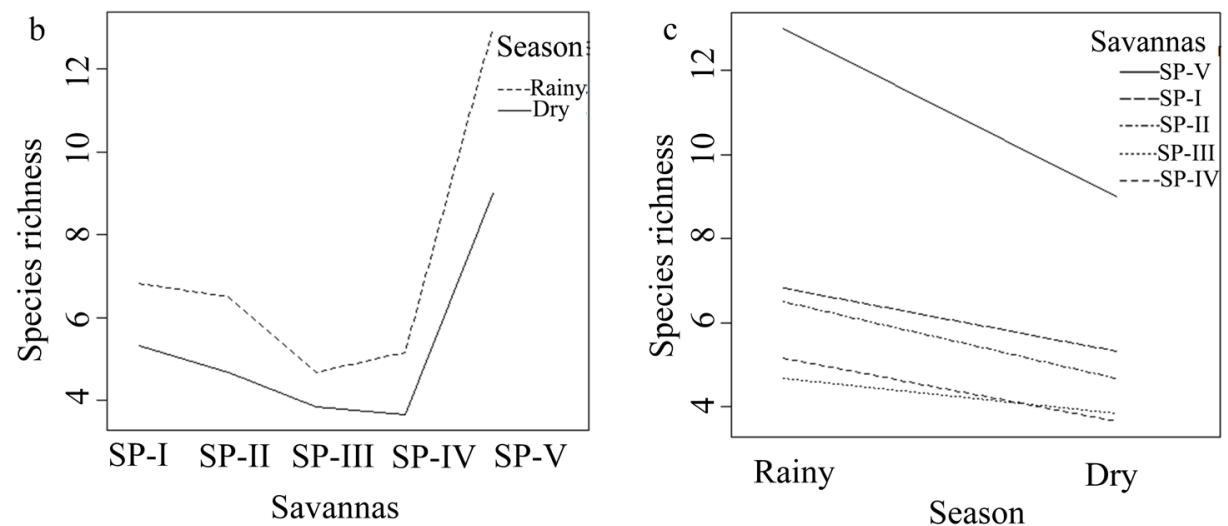

group with great importance to the conservation influenced by seasonality, considering that most of biological diversity.

\section{Species composition}

The results indicated that the composition was influenced by local conditions of the habitat rather than by seasonality. Since, although all areas were classified as Park Savanna, differences were observed in terms of density of host trees and soil drainage influenced by riverine forests. Rainfall occurs throughout the year in the Amazon, but two rain periods can be distinguished: one rainiest season influenced by the Intertropical Convergence Zone (ITCZ), and another dry season, with undefined dry season (Fisch et al. 1998). In this sense, the results were expected that the composition would not be bryophytes are perennial with life cycles with more than one year (necessary for a reproductive cycle and ripening of the spores) and therefore live both wet and dry seasons several times (Geissler 1982). On the other hand, a minority of bryophytes are ephemeral with very short life cycles that probably vary with seasonality, such as the moss model Physcomitrium (Cove et al. 2006).

SP-V presented 11 exclusive species, nine of which occurred in live trunks and two in dead trunks. These results indicate that the amount of host trees, light incidence, and the structural and chemical conditions of the substrates are vital for the creation of different microhabitats (Hylander 2009, Sundberg 2013, Lonnell et al. 
2014). These conditions act as environmental filters that influence the composition of the bryoflora (Raabe et al. 2010) and shape plant communities (Mota-de-Oliveira \& ter Steege 2015).

The predominance of Lejeuneaceae in the sampled savannas is explained by the fact that this family comprises about $70 \%$ of Amazonian bryophyte richness, due to its wide morphological plasticity that allows the colonization of different environments and height zones in host trees (Gradstein et al. 2001, Oliveira \& ter Steege 2013, Mota-de-Oliveira 2018). However, in spite of the greater richness of Lejeuneaceae, the number of occurrences recorded in the sampled savannas

Table III. Fisher's alpha values calculated for the bryophyte community.

\begin{tabular}{|c|c|c|c|}
\hline & Taxa & Individuals & $\alpha$ \\
\hline \multicolumn{4}{|l|}{ Savanna } \\
\hline SP-I & 20 & 128 & 6.64 \\
\hline SP-II & 16 & 160 & 4.42 \\
\hline SP-III & 12 & 99 & 3.57 \\
\hline SP-IV & 18 & 108 & 6.18 \\
\hline$S P-V$ & 32 & 325 & 8.80 \\
\hline \multicolumn{4}{|l|}{ Rainy season } \\
\hline SP-I & 18 & 70 & 7.84 \\
\hline SP-II & 15 & 80 & 5.45 \\
\hline SP-III & 10 & 40 & 4.28 \\
\hline SP-IV & 13 & 61 & 5.06 \\
\hline$S P-V$ & 27 & 198 & 8.44 \\
\hline \multicolumn{4}{|l|}{ Dry season } \\
\hline SP-I & 14 & 58 & 5.86 \\
\hline SP-II & 11 & 80 & 3.45 \\
\hline SP-III & 11 & 59 & 3.98 \\
\hline SP-IV & 11 & 47 & 4.52 \\
\hline SP-V & 21 & 127 & 7.16 \\
\hline \multicolumn{4}{|l|}{ Total } \\
\hline Dry season & 31 & 371 & 8.047 \\
\hline Rainy season & 36 & 449 & 9.216 \\
\hline
\end{tabular}

was not as high as that of Calymperaceae and Sematophyllaceae. Similar results were found by Bôas-Bastos \& Bastos (1998) in a savanna in Bahia, where Frullaniaceae and Lejeuneaceae were the only liverwort families present. Such families have great ecological amplitude and are common in xerophytic vegetation, although they are usually represented by few occurrences. These families were also the most represented among liverworts recorded in savannas of the Federal District (Câmara \& Leite 2005), Goiás (Pinheiro et al. 2012, Aquino et al. 2015, Rios et al. 2016) and Maranhão (Oliveira et al. 2018, Costa et al. 2018).

The predominance of acrocarpous moss families is common in open, sunny, dry, xeric or anthropic habitats (Bastos \& Bôas-Bastos 2008, Širka et al. 2019) because these taxa are more resistant to dehydration (Govindapyari et al. 2012). For example, turf life form, leaves imbricate and slightly folded, smaller leaves, lengthy costa, leaves with papilla, leaves with hairpoint and hyalocysts/hyaline cells, confers desiccation resistance the acrocarpous mosses and are the result of xerophytic adaptations (Watson 1914, Frahm 2003, Kürschner 2004, Kürschner \& Parolly 2005, Henriques et al. 2017). Similar results were recorded in savanna of Minas Gerais, where acrocarpous mosses accounted for roughly 53\% of moss species (Sousa \& Câmara 2015). The moss families recorded in this study were also found in savannas of the Central Plateau (Câmara \& Leite 2005, Câmara et al. 2005, Peralta et al. 2008, Sousa et al. 2010, Porfírio-Júnior et al. 2016).

Calymperaceae and Sematophyllaceae particularly prominent families as colonizers of disturbed or dry environments in the Amazon, represented mainly by Calymperes palisotii Schwägr., Microcalpe subsimplex (Hedw.) W.R. Buck and Octoblepharum albidum Hedw. (Bastos \& Yano 1993, Lisboa \& Ilkiu-Borges 1995, Visnadi 

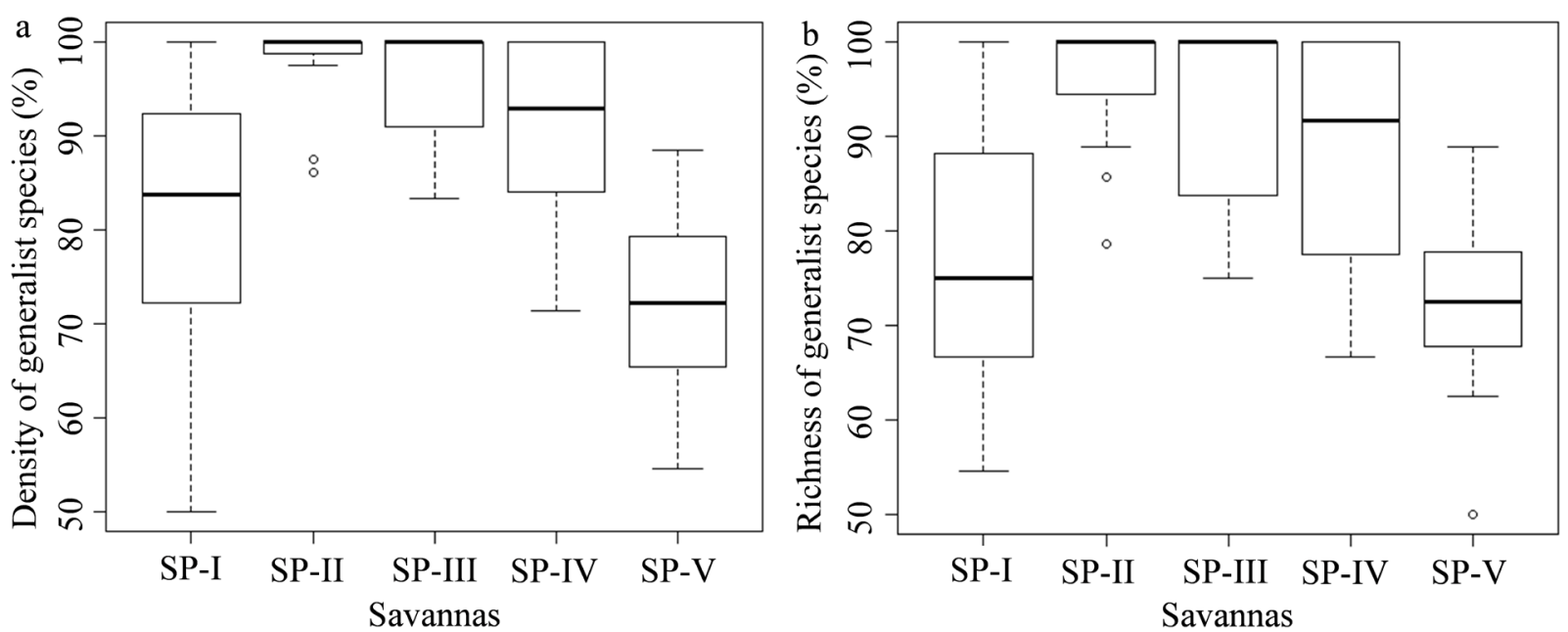

Figure 6. Generalist species in the sampled areas. (a) Density; (b) Richness.

\& Monteiro 1990). The peculiar physiological characteristics of these groups confers them specialized desiccation tolerance mechanisms (Wagner et al. 2014).

The greater abundance of mosses than liverworts in dry sites may be related to more members of this lineage having specialized morphological, anatomical, and physiological traits of desiccation tolerance (Proctor \& Tuba 2002, Proctor et al.2007, Goffinet et al. 2009), which can survive successfully in deserts or extreme environments, especially at high temperatures (Mertens et al. 2008). As for example, dry mosses can survive at exposed temperatures of habitats above 70-110 으 (Lange 1955), some up to 85-110 oC, while moist mosses are damaged or do not survive at temperatures of 42-51 으 (Nörr 1974). Among the morphological traits associated with desiccation tolerance in mosses, stand out the coast of leaves that aid in rapid absorption and transport of water, in addition to structural support to leaves during desiccation (Frahm 1985); hyaline cells at the base of the leaves that store water to prevent desiccation (Frahm 2003) and turf life forms and acrocarpous habit, which decreases water loss by evaporation and reduces radiation damage to photosynthetic cells, optimizes water absorption rain or air humidity (Vitt 1979, Kürschner 2004).

Among the most frequent taxa that were shared among the savannas and seasons, Calymperes palisotii Schwägr., Microcalpe subsimplex (Hedw.) W.R. Buck and Octoblepharum albidum Hedw. stood out; they have hyaline cells that accumulate water to prevent desiccation and protect photosynthetic cells from sun damage (Kürschner 2004). The greater occurrence of Calymperes erosum Müll. Hal. in the rainy season (35 against 15) is in line with the ecological descriptions made by Lisboa (1993), who portrayed this species as widely distributed in humid places such as riverine forests or also in more open areas such as savannas. Thus, C. erosum has become an important model to understand the dynamics of Amazonian savannas, since its greater occurrence has been associated to the recovery of degraded areas (Lopes et al. 2016).

Among liverworts, the species Acrolejeunea torulosa (Lehm. \& Lindenb.) Schiffn., Cheilolejeunea oncophylla (Aongström) Grolle \& E.Reiner, Cheilolejeunea rigidula (Nees ex Mont.) R.M. Schust. and Microlejeunea epiphylla Bischl. are cited for the Amazon as 
having morphological traits influenced by the microclimatic conditions of the different height zones of host trees (Mota-de-Oliveira 2018), with asexual propagules, convoluted leaves and cell wall thickening observed more frequently in the canopy, where irradiance is more intense.

\section{Density, richness and diversity}

The low values of density and richness of the savannas sampled in comparison to other tropical ecosystems may be related to their microclimatic conditions such as intense light incidence and low water availability. These conditions act as environmental filters determining the number and mutual species that can coexist, implying the sharing of resources (Slack 1990) and prevent the coexistence of species in long-term equilibrium (Werner 1979). Thus, only the most tolerant species are able to establish in the climatic conditions of this environment (Bello et al. 2010, Smith \& Stark 2014). The variations in density and richness patterns observed in the communities of SP-V in relation to the other areas may be associated with a greater amount of resources present in the environment (Corrales et al. 2010) and high variability of microhabitats with favorable conditions for colonization, respectively (Holz et al. 2002).

Most mosses and liverworts species are perennial, some exceptions such as Archidium globiferum and Riccia are annual, respectively (Frahm 1996). In this sense, the greatest exclusive occurrence of species recorded during the rainy season of this study can be explained by the passage of fire in the dry season that often affects vegetation, where extreme ecological conditions reduce the species number of bryophyte (Frahm 1996), in addition, fire is a factor that reduces the chances of developing a diversified bryoflora (Inácio-Silva et al. 2017).
In this study, the richness of bryophyte communities followed the same pattern of other Amazonian lowland ecosystems, in which the specific richness of liverworts is always greater than that of mosses (Richard 1984, Brito \& IlkiuBorges 2013, Garcia et al. 2014, Pantoja et al. 2015, Fagundes et al. 2016). On the other hand, the pattern of number of occurrences found was similar to that recorded in dry forests, as is the case of savannas of the Central Plateau, where mosses are better represented in terms of richness and occurrences than liverworts (BôasBastos \& Bastos 1998, Visnadi 2004, Câmara et al. 2005, Aquino et al. 2015, Rios et al. 2016, Costa et al. 2018, Oliveira et al. 2018).

The low diversity of bryophytes recorded in the studied savannas may be related to the microclimatic conditions, which result from the interaction between substrate quality, $\mathrm{pH}$, temperature, light and humidity (Weibull \& Rydi 2005). Among the intrinsic conditions of this vegetation, the prevalent prolonged droughts and lack of nutrients hinder the succession of new species that are not adapted to this ecosystem (Franco 2005). As observed by Bastos \& Bôas-Bastos (2008), the diversity of bryophytes is affected by the regime of fires, as well as by the low availability of water in savannas, for they affect the reproduction and development of these plants. On the other hand, Holz et al. (2002) pointed out that the high diversity of bryophytes found in dense forests occurs due to the great diversification of microhabitats that are distributed from the base to the canopy of trees, as well as in rotting trunks and soil.

\section{Ecological groups}

The greater abundance of the generalist species is associated with areas under environmental disturbance (Pantoja et al. 2015, Fagundes et al. 2016) or areas that are typically open (like savannas). Generalist species possess great 
ecological amplitude and greater desiccation tolerance (Lopes et al. 2016). The widespread occurrence of generalist species in the sampled areas demonstrates their tolerance to xerophytic environments, colonizing several substrate types and occurring near forest edges and in more open areas with high light levels (Cerqueira et al. 2015). Brito \& Ilkiu-Borges (2013) reported seven generalist species for the savannas of the municipality of Soure, namely, Calymperes palisotii Schwägr., Cheilolejeunea oncophylla (Aongström) Grolle \& E.Reiner, Cheilolejeunea rigidula (Nees ex Mont.) R.M. Schust. and Lejeunea laetevirens Nees \& Mont. These generalist species are also found in the present study. Other species, including Microcalpe subsimplex (Hedw.) W.R. Buck and Octoblepharum albidum Hedw., are cited by Brito \& Ilkiu-Borges (2014) as the best adapted taxa for growth and establishment in a variety of environmental conditions.

The absence of canopy in the savannas and increased availability of light (Ribeiro \& Walter 2008) allowed the sun specialists to be found along different gradients, from the base to the top of the trees and shrubs, because light levels and desiccation tolerance are linked and crucial factors that influence the distribution of bryophytes (Király et al. 2013). Shade specialists were also rarely found near the treetops, because they are more common in moist and shaded forests (Gradstein et al. 2001). According to Wagner et al. (2014), species with lower desiccation tolerance do not resist the high light incidence and water stress, and they are therefore mostly excluded from the environment.

\section{Distribution of bryophytes in the substrates}

The highest incidence of corticolous species in this study (88\%) is also predominant in nonflooded forests in the Amazon (Saldanha et al.
2018, Oliveira-da-Silva \& Ilkiu-Borges 2018) and savannas of the Central Plateau (Aquino et al. 2015). Decomposing trunks are the following most colonized substrate (Richards 1984). The greater availability of live trunks and increased $\mathrm{pH}$ and water retention capacity of barks (Studlar 1982, Richards 1984, Hallingbäck \& Hodgetts 2000) are favorable conditions for the colonization of bryophytes with limited desiccation tolerance mechanisms (Proctor \& Tuba 2002, Proctor 2008, Oliveira-da-Silva \& Ilkiu-Borges 2018). It is believed that host trees available in savannas are the refuge of bryophytes which seek greater availability of water, where bryophytes are often observed in humid microhabitats such as cracks in tree trunks. Thus, to ensure the maintenance of the communities of bryophytes it is essential that there be the conservation of the plant community, since the richness of species of bryophytes and vascular plants is positively correlated (Ingerpuu et al. 2001).

The abundance of corticolous species observed in this study is distinct from the pattern found in dense tropical forests with high levels of precipitation. In these forests, substrate preference is neutralized by high humidity; most species have weak or no preference for substrate types, and are able to colonize a variety of available environments (Frahm 2003). Germano \& Pôrto (2006) pointed out that $87 \%$ of the bryophytes of a remnant area of the Atlantic Forest with high annual precipitation $(2,450 \mathrm{~mm})$ did not show strong preferences for specific substrates.

The exclusive occurrence of Fissidens prionodes Mont. in soil and the low representation of terrestrial species (1.95\%) may be related to the variety of morphological traits of this genus, such as presence of limbidium and papillae that act in desiccation tolerance (Pursell 2007, Bordin \& Yano 2013). The chemical composition of the soil of savannas, particularly 
the acidity, high saturation of aluminum, poor drainage, and low fertility, may be a hindering factor for the colonization of species other, less specialized (Cavalcante et al. 2014). These conditions reinforce the general idea that soil acidification may be responsible for the decline of bryophyte richness (Delgado \& Ederra 2013). Müller et al. (2019) observed that the richness of terrestrial bryophytes decreased with decreasing soil pH in managed forests of Central Europe. Moreover, the abundant grass layer mainly represented by Poaceae and Cyperaceae in the sampled savannas (Bastos 1984) may be a limiting factor for terrestrial bryophytes, as observed by Jagodziński et al. (2015), who reported that grasses competed with bryophytes in the soil.

\section{CONCLUSION}

This study reveals that bryophytes in savannas of the Marajó Island are well adapted to the environmental conditions of this ecosystem, indicated by the high representation of the generalists and sun specialists among the species, with specialized desiccation tolerance strategies. It was observed that despite the greater availability of water in the rainy season, there is no sufficient succession of new species to prove the influence of this abiotic variable on the structure of the bryophyte communities. In this context, these results were expected, since most bryophytes are perennials, whose life cycle is longer than one year and would be found in both wet and dry seasons. In turn, differences between the sampled areas were the main factor explaining the changes in the composition, richness, density, and diversity of bryophytes.

The sampled savannas presented a richness of bryophytes similar to the other Amazonian ecosystems and the number of occurrences had the same pattern of representation of savannas from the Central Plateau, where mosses are more abundant despite lower levels of species richness than liverworts. Finally, the high frequency of rare species endorses the need for conservation of this ecosystem.

\section{REFERENCES}

ALVARENGA LDP \& LISBOA RCL. 2009. Contribuição para o conhecimento da taxonomia, ecologia e fitogeografia de Briófitas da Amazônia Oriental. Acta Amaz 39: 495-504.

AQUINO HF, RESENDE ILM, PERALTA DF \& ROCHA LM. 2015. Bryoflora of Gallery Forest in Quirinópolis, Goiás State, Brazil. Hoehnea 42: 419-424.

AYRES M, AYRES-ÚNIOR M, AYRES DL \& SANTOS AA. 2007. BIOESTAT - Aplicações estatísticas nas áreas das Ciências Bio-Médicas. Belém: Mamirauá, 364 p.

BASTOS CJP \& BÔAS-BASTOS SBV. 2008. Musgos acrocárpicos e cladocárpicos (Bryophyta) da reserva ecológica da Michelin, Igrapiúna, Bahia, Brasil. Sitientibus, Sér Ciên Biol 8: 275-279.

BASTOS CJP \& YANO O. 1993. Musgos da zona urbana de Salvador, Bahia. Hoehnea 20: 21-31.

BASTOS MNC. 1984. Levantamento florístico dos campos do Estado do Pará. I - Campo de Joanes (Ilha de Marajó). Bol Mus Para Goeldi 1: 67-86.

BELLO F ET AL. 2010. Towards an assessment of multiple ecosystem processes and services via functional traits. Biodiver Conserv 19: 2873-2893.

BÔAS-BASTOS SBV \& BASTOS CJP. 1998. Briófitas de uma área de Cerrado no município de Alagoinhas, Bahia, Brasil. Trop Bryol 15: 101-110.

BORDIN I \& YANO O. 2013. Fissidentaceae (Bryophyta) do Brasil. Bol Inst Bot 22: 1-72.

BRITO ES \& ILKIU-BORGES AL. 2013. Bryoflora of the municipalities of Soure and Cachoeira do Arari, on Marajó Island, in the state of Pará, Brazil. Acta Bot Bras 27: 124-141.

BRITO ES \& ILKIU-BORGES AL. 2014. Briófitas de uma área de Terra Firme no município de Mirinzal e novas ocorrências para o estado do Maranhão, Brasil. Iheringia, Sér Bot 69: 133-142. 
BUCK WR. 2003. Guide to the Plants of Central French Guiana. Part 3. Mosses. (Memoirs of the New York Botanical Garden 76). The New York Bot Gar Press, New York.

CÂMARA PE \& LEITE RN. 2005. Bryophytes from Jalapão, state of Tocantins, northern Brazil. Trop Bryol 26: 23-29.

CÂMARA PEAS, OLIVEIRA JRPM \& SANTIAGO MMM. 2005. A checklist of the bryophytes of Distrito Federal (Brasilia, Brazil). Trop Bryol 26: 133-140.

CARVALHO WD \& MUSTIN K. 2017. The highly threatened and little-known Amazonian savannahhs. Nat Ecol Evol 1: 1-3.

CAVALCANTE CO, FLORES AS \& BARBOSA RI. 2014. Fatores edáficos determinando a ocorrência de leguminosas herbáceas em savanas amazônicas. Acta Amaz 44: 379-386.

CERQUEIRA GR, ILKIU-BORGES AL, MANZATTO AG \& MACIEL S. 2015. Briófitas de um fragmento de floresta ombrófila aberta no município de Porto Velho e novas ocorrências para Rondônia, Brasil. Biota Amaz 5: 71-75.

CORRALES A, DUQUE A, URIBE J \& LONDOÑO J. 2010. Abundance and diversity patterns of terrestrial bryophyte species in secondary and planted montane forests in the northern portion of the Central Cordillera of Colombia. Bryologist 113: 8-21.

COSTA AMR, OLIVEIRA RR, SÁ NAS \& CONCEIÇÃO GM. 2018. Briófitas do Cerrado Maranhense, Nordeste do Brasil. Rev NBC 8: 33-45.

COSTA DP \& PERALTA DF. 2015. Bryophytes diversity in Brazil. Rodriguésia 66(4): 1-9.

COVE D, BEZANILLA M, HARRIES P \& QUATRANO R. 2006. Mosses as model systems for the study of metabolism and development. Annu Rev Plant Biol 57: 497-520.

CRANDALL-STOTLER B, STOTLER RE \& LONG DG. 2009. Morphology and classification of the Marchantiophyta. In: Goffinet B \& Shaw AJ (Eds), Bryophyte Biology, $2^{\text {nd }}$ ed., University Press Cambridge, Cambridge, p. 1-54.

DELGADO V \& EDERRA A. 2013. Long-term changes (19822010) in the biodiversity of Spanish beech forests assessed by means of Ellenberg indicator values of temperature, nitrogen, light and $\mathrm{pH}$. Biol Conserv 157: 99-107.

DORREPAAL E, AERTS R, CORNELISSEN JHC, CALLAGHAN TV \& VAN LOGTESTIJN RSP. 2004. Summer warming and increased winter snow cover affect Sphagnum fuscum growth, structure and production in a sub-arctic bog. Glob Change Biol 10: 93-104.
DUFRÊNE M \& LEGENDRE P. 1997. Species assemblages and indicator species: the need for flexible asymmetrical approach. Ecol 67: 345-366.

DUNN OJ. 1964. Multiple comparisons using rank sums. Technometrics 6: 241-252.

ELMENDORF SC ET AL. 2012. Global assessment ofexperimental climate warming on tundra vegetation: heterogeneity overspace and time. Ecol Lett 15: 164-175.

FAGUNDES DN, TAVARES-MARTINS AC, ILKIU-BORGES AL, MORAES ER \& SANTOS RCP. 2016. Riqueza e aspectos ecológicos das comunidades de briófitas (Bryophyta e Marchantiophyta) de um fragmento de Floresta de Terra Firme no Parque Ecológico de Gunma, Pará, Brasil. Iheringia, Sér Bot 71: 72-84.

FEARNSIDE PM. 2015. Pesquisa sobre conservação na Amazônia brasileira e a sua contribuição para a manutenção da biodiversidade e uso sustentável das florestas tropicais. In: Vieira I, Jardim M \& Rocha E. Amazônia em Tempo: Estudos Climáticos e Socioambientais. Universidade Federal do Pará, Museu Paraense Emílio Goeldi and Embrapa Amazônia Oriental, Belém, p. 21-49.

FISCH G, MARENGO JA \& NOBRE CA. 1998. Uma Revisão Geral Sobre O Clima da Amazônia. Acta Amaz 28: 101-126.

FLORSCHÜTZ-DE WAARD J. 1996. Sematophyllaceae. Musci III. In: Görts-Van Rijn ARA (Ed), Flora of the Guianas. Series C: Bryophytes Fascicle 1: 439-462.

FRAHM JP. 1985. A Bryophyte in an Ant Garden. Bryol Times 34(1).

FRAHM JP. 1996. Diversity, life strategies, origins and distribution of tropical inserlberg bryophytes. An Inst Biol/Bot 67(1): 73-86.

FRAHM JP. 2003. Manual of tropical Bryology. Trop Bryol 23: 1-196.

FRANCO AC. 2005. Biodiversidade de forma e função: implicações ecofisiológicas das estratégias de utilização de água e luz em plantas lenhosas do Cerrado. In: Scariot A, Sousa-Silva JC \& Felfili JM (Eds), Cerrado: Ecologia, Biodiversidade e Conservação. Ministério do Meio Ambiente: Brasília-DF, p. 179-196.

GARCIA ET, ILKIU-BORGES AL \& TAVARES-MARTINS ACC. 2014. Brioflora de duas florestas de terra firme na Área de Proteção Ambiental do Lago de Tucuruí, PA, Brasil. Hoehnea 41: 499-514.

GEISSLER P. 1982. Alpine Communities. In: Smith AJE (Ed), Bryophyte Ecology. Springer: Dordrecht, p. 167-189. 
GERMANO SR \& PÔRTO KC. 2006. Bryophyte communities in Atlantic forest remnant, state of Pernambuco, Brazil. cryptogam Bryol 27: 153-163.

GLIME JM. 2017. Field Taxonomy and Collection Methods. Chapt. 1. In: Glime JM (Ed), Bryophyte Ecology. V. 3. Methods. Ebook Michigan Technological University and the International Association of Bryologists, 20 p.

GOFFINET B, BUCK WR \& SHAW AJ. 2009. Morphology, anatomy, and classification of the Bryophyta. In: Goffinet B \& Shaw AJ (Eds), Bryophyte Biology, $2^{\text {nd }}$ ed., University Press Cambridge: Cambridge, p. 55-138.

GOSSELIN M, FOURCIN D, DUMAS Y, GOSSELIN F, KORBOULEWSKY N, TOÏGO M \& VALLET P. 2017. Influence of forest tree species composition on bryophytic diversity in mixed and pure pine (Pinus sylvestris L.) and oak (Quercus petraea (Matt.) Liebl.) stands. For Ecol Manage 406: 318-329.

GOVINDAPYARI H, KUMARI P, BAHUGUNA YM \& UNIYAL PL. 2012. Evaluation of species richness of acrocarpous mosses in Imphal District, Manipur, India. Taiwania 57: 14-26.

GRADSTEIN SR, CHURCHILL SP \& SALAZAR-ALLEN N. 2001. Guide to the bryophytes of tropical America (Memoirs of the New York Botanical Garden, 86). The New York Bot Gar Press, New York.

GRADSTEIN SR \& ILKIU-BORGES AL. 2009. Guide to the Plants of Central French Guiana. Part 4. Liverworts and Hornworts. (Memoirs of the New York Botanical Garden 76). The New York Bot Gar Press, New York.

HALLINGBÄCK T \& HODGETTS N. 2000. Mosses, Liverworts, and Hornworts. Status Survey and Conservation Action Plan for Bryophytes. IUCN/SSC Bryophyte Specialist Group. IUCN, Gland, Switzerland and Cambridge, 106 p.

HE X, HEB KS \& HYVÖNEN J. 2016. Will bryophytes survive in a warming world? PERSPECT Plant Ecol 19: 49-60.

HENRIQUES DSG, AH-PENG C \& GABRIEL R. 2017. Structure and applications of BRYOTRAIT-AZO, a trait database for Azorean bryophytes. Cryptogam Bryol 38: 137-152.

HESPANHOL H, SÉNECAA A, FIGUEIRA R \& SÉRGIO C. 2011. Microhabitat effects on bryophyte species richness and community distribution on exposed rock outcrops in Portugal. Plant Ecol Divers 4: 251-264.

HOFFMANN WA, JACONIS S, MCKINLEY K, GEIGER E, GOTSH S \& FRANCO AC. 2012. Fuels or microclimate? Understanding the drivers of fire feedbacks at savannah forest boundaries. Aust Ecol 37: 634-643.

HOLZ I, GRADSTEIN SR, HEINRICHS J \& KAPPELLE M. 2002. Bryophyte diversity, microhabitat differentiation and distribution of life forms in Costa Rican upper montane Quercus forest. Bryologist 105: 334-348.

HSIEH TC, MA KH \& CHAO A. 2013. iNEXT online: interpolation and extrapolation (Version 1.0) [Software]. Available in: http://chao.stat.nthu.edu.tw/blog/software-download/.

HYLANDER K. 2009. No increase in colonization rate of boreal bryophytes close to propagule sources. Ecol 90: 160-169.

IBGE. 2012. Manual Técnico da Vegetação Brasileira. $2^{\text {nd }}$ ed., Rio de Janeiro: Departamento de Recursos Naturais e Estudos Ambientais, $271 \mathrm{p}$.

INÁCIO-SILVA M, CARMO DM \& PERALTA DF. 2017. As espécies brasileiras endêmicas de Campylopus Brid. (Bryophyta) estão ameaçadas? Uma análise usando modelagem para avaliar os seus estados de conservação. Hoehnea 44(3): 464-472.

INGERPUU N, VELLAK K, KUKK T \& PÄRTEL M. 2001. Bryophyte and vascular plant species richness in boreo-nemoral moist forests and mires. Biodivers Conserv 10: 2153-2166.

JAGODZIŃSKI AM, DYDERSKI MK, GDULA AK, RAWLIK M \& KASPROWICZ M. 2015. Zróżnicowanie flory roślin naczyniowych runa pod drzewostanami powstałymi w wyniku rekultywacji zwałowiska pokopalnianego. Stud. Mater. CEPL W Rogowie 42: 249-261.

KIRÁLY I, NASCIMBENE J, TINYA F \& ODOR P. 2013. Factors influencing epiphytic bryophyte and lichen species richness at different spatial scales in managed temperate forests. Biodiv Conserv 22: 209-223.

KÜRSCHNER H. 2004. Life strategies and adaptations in bryophytes from the nearand Middle east. Turkish J Bot 28: 73-84.

KÜRSCHNER H \& PAROLLY G. 2005. Ecosociological studies in Ecuadorian bryophyte communities III. Life forms, life strategies and ecomorphology of the submontane and montane epiphytic vegetation of S Ecuador. Nova Hedwigia 80: 89-113.

LANG SI, CORNELISSEN JHC, HOELZER A, TER BRAAK CJF, AHRENS M, CALLAGHAN TV \& AERTS R. 2009. Determinants of cryptogam composition and diversity insphagnumdominated peatlands: the importance of temporal, spatial andfunctional scales. J Ecol 97: 299-310.

LANGE OL. 1955. Untersuchungen über die Hitzeresistenz der Moose in Beziehung zu ihrer Verbreitung. I. Die Resistenz stark ausgetrockneter Moose. Flora Allg Bot Zeit 142: 381-399. 
LISBOA RCL. 1993. Musgos Acrocárpicos do Estado de Rondônia. Mus Para Emílio Goeldi, Coleção Adolpho Ducke, $272 \mathrm{p}$.

LISBOA RCL \& ILKIU-BORGES AL. 1995. Diversidade das Briófitas de Belém (PA) e seu potencial como indicadoras de poluição. Bol Mus Para Emílio Goeldi 11: 199-225.

LONNELL N, JONSSON BG \& HYLANDER K. 2014. Production of diaspores at the landscape level regulates local colonisation: an experiment with a spore-dispersed moss. Ecography 37: 591-598.

LOPES MO, PIETROBOM MR, CARMO DM \& PERALTA DF. 2016. Estudo comparativo de comunidades de briófitas sujeitas a diferentes graus de inundação no município de São Domingos do Capim, PA, Brasil. Hoehnea 43: 159-171.

MAGURRAN AE. 1988. Ecological diversity and its measurement. New Jersey: Princeton University Press, Princeton.

MERTENS J, BELADJAL L, ALCANTARA A, FOUGNIES L, STRAETEN DVD \& CLEGG JS. 2008. Sobrevivência de eucariotos secos (anidrobiotes) após exposição a temperaturas muito altas. Rev Biol Soc Linn 93: 15-22.

MOTA-DE-OLIVEIRA S. 2018. The double role of pigmentation and convolute leaves in Community assemblage of Amazonian epiphytic Lejeuneaceae. Peerj 6: 1-15.

MOTA-DE-OLIVEIRA S \& TER STEEGE H. 2015. Bryophyte communities in the Amazon forest are regulated by height on the host tree and site elevation. J Ecol 103: 441-450.

MÜLLER J, BOCHC S, PRATIC D, SOCHERC AS, POMMERA U, HESSENMÖLLERE D, SCHALLI P, SCHULZEE ED \& FISCHERC $M$. 2019. Effects of forest management on bryophyte species richness in Central European forests. For Ecol Manage 432: 850-859.

MUSTIN K ET AL. 2017. Biodiversity, threats and conservation challenges in the Cerrado of Amapá, an Amazonian savana. Nat Conserv 22: 107-127.

MYERS N, MITTERMEIER RA, MITTERMEIER CG, FONSECA GAB \& KENT J. 2000. Biodiversity hotspots for conservation priorities. Nat 403: 853-858.

NÖRR M. 1974. Hitzeresistenz bei Moosen. [Heat resistance of mosses.]. Flora 163: 388-397.

OKSANEN J, KINDT R, LEGENDRE P, O'HARA B, HENRY M \& STEVENS H. 2007. Vegan: Community Ecology Package. R package, version 1.8-8. 2007. Available in: http://cran.r-project. org/, http://r-forge.r-project.org/ projects/vegan/.
OLIVEIRA-DA-SILVA FR \& ILKIU-BORGES AL. 2018. Briófitas (Bryophyta e Marchantiophyta) das cangas da Serra dos Carajás, Pará, Brasil. Rodriguésia 69: 1405-1416.

OLIVEIRA RR, MEDEIROS DL, OLIVEIRA HC \& CONCEIÇÃO GM. 2018. Briófitas de área sob o domínio fitogeográfico do Cerrado e novas ocorrências para o Maranhão e região Nordeste do Brasil. Iheringia, Sér Bot 73: 191-195.

OLIVEIRA SM \& TER STEEGE H. 2013. Floristic overview of the epiphytic bryophytes of terra firme forests across the Amazon basin. Acta Bot Bras 27: 347-363.

PANTOJA ACC, ILKIU-BORGES AL, TAVARES-MARTINS ACC \& GARCIA ET. 2015. Bryophytes in fragments of Terra Firme forest on the great curve of the Xingu River, Pará state, Brazil. Braz J Biol 75: 238-249.

PARDOW A \& LAKATOS M. 2013. Desiccation tolerance and global change: implications for tropical bryophytes in lowland forests. Biotropica 45: 27-36.

PERALTA DF, BORDIN J \& YANO O. 2008. New mosses records (Bryophyta) for Goiás and Tocantins states, Brazil. Acta Bot Bras 22: 834-844.

PINHEIRO EMA, FARIA ALA \& CÂMARA PEAS. 2012. Riqueza de espécies e diversidade de Marchantiophyta (hepáticas) de Capões de Mata, no Parque Nacional da Chapada dos Veadeiros, Goiás, Brasil. Rev Biol Neotrop 9: 19-27.

PLOTKIN RL \& RIDING S. 2011. Biogeography of the Llanos de Moxos: natural and anthropogenic determinants. Biogeogr Llanos Moxos 66: 183-192.

PORFÍRIO-JÚNIOR ED, ARAÚJO WS \& GOMES-KLEIN VL. 2016. Efeito da cobertura de palmeiras e da distância da floresta sobre a distribuição de musgos na Floresta Nacional de Silvânia, Goiás, Brasil. Rev Biol Neotrop 13: $1-7$.

PRANCE GT. 1996. Islands in Amazonia. Philos Trans Royal Soc/London 351: 823-833.

PROCTOR MCF. 2008. Physiological ecology. In: Goffinet B \& Shaw AJ (Eds), Bryophyte Biology, $2^{\text {nd }}$ ed., University Cambridge Press, Cambridge, p. 237-267.

PROCTOR MCF, OLIVER MJ, WOOD AJ, ALPERT P, STARK LR, CLEAVITT NL \& MISHLER BD. 2007. Desiccation-tolerance in bryophytes: a review. Bryologist 110(4): 595-621.

PROCTOR MCF \& TUBA Z. 2002. Poikilohydry and Homeohydry: Antitheses or spectrum of possibilities? New Phytologist 156: 327-349.

PURSELL RA. 2007. Fissidentaceae. Flora Neotrop 101: 1-278.

R CORE TEAM. 2018. R: A language and environment for statistical computing. R Foundation for Statistical 
Computing, Vienna, Austria. Available in: https://cran.rproject.org/bin/windows/base/old/3.1.3/.

RAABE S, MÜLLER J, MANTHEY M, DÜRHAMMER O, TEUBER U, GÖTTLEIN A, FÖRSTER B, BRANDL R \& BÄSSLER C. 2010. Drivers of bryophyte diversity allow implications for forest management with a focus on climate change. For Ecol Manage 260: 1956-1964.

RIBEIRO JF \& WALTER BMT. 2008. As Principais Fitofisionomias do Bioma Cerrado. In: Sano SM, Almeida SP \& Ribeiro JF (Eds), Cerrado: Ecologia e Flora. Brasília-DF: Embrapa, $406 \mathrm{p}$.

RICHARDS PW. 1984. The Ecology of tropical forest bryophytes. In: Schuster RM (Ed), New Manual of Bryology. Hattori Botanical Laboratory 2, Nichinan, Japan, p. 1233-1269.

RIOS ABM, OLIVEIRA JPS, SILVA RP, OLIVEIRA-NETO JF, OLIVEIRA LS, PERALTA DF \& MACCAGNAN DHB. 2016. Bryophyte diversity in an area of Brazilian Cerrado in Central-West. Neotrop Biol Conserv 11: 132-140.

ROBBINS RG. 1952. Bryophyta Ecology of a dune area in New Zealand. Vegetation. Acta Geobot 4: 1-31.

ROSSETTI DF, VALERIANO MM \& THALLÊS M. 2007. An abandoned estuary within Marajó Insland: implications for late quaternary paleogeography of northern Brazil. Estuar Coasts 30: 813-826.

SALDANHA LS, PINTO MN, ALMEIDA R, SANTOS VS \& LIMA RA. 2018. Caracterização morfológica de briófitas no Município de Benjamin Constant-AM. Biota Amaz 8: 48-52.

SANTOS ND, COSTA DP, KINOSHITA LS \& SHEPHERD GJ. 2014. Windborne: Can liverworts be used as indicators of altitudinal gradient in the Brazilian Atlantic Forest? Ecol Indicators 36: 431-440.

SCHILLING AC \& BATISTA JLF. 2008. Curva de acumulação de espécies e suficiência amostral em florestas tropicais. Rev Bras Bot 31: 179-187.

SILVA GFN \& OLIVEIRA IJ. 2018. Reconfiguração da paisagem nas savanas da Amazônia. Mercator 17: 1-20.

SILVA MPP \& PÔRTO KC. 2007. Composição e riqueza de briófitas epíxilas em fragmentos florestais da Estação Ecológica de Murici, Alagoas. Rev Bras Biociênc 5: 243-245.

ŠIRKA P, GALVÁNEK D, TURISOVÁ I \& SABOVLJEVIĆ M. 2019. What are the main drivers affecting the pattern of bryophyte life history traits at two contrasting spoil heaps? Flora 253: 17-26.

SLACK NG. 1990. Bryophytes and ecological niche theory. Bot J Linnean Soc 104: 187-213.
SMITH RJ \& STARK LR. 2014. Habitat vs. dispersal constraints on bryophyte diversity in the Mojave Desert, USA. J Arid Environ 102: 76-81.

SOUSA MAR, GOMES-KLEIN VL \& YANO O. 2010. Musgos (Bryophyta) do Parque Estadual da Serra dos Pireneus, Goiás, Brasil. Rev Biol Neotrop 7: 7-26.

SOUSA RV \& CÂMARA PEAS. 2015. Survey of the bryophytes of a gallery forest in the National Park of Serra do Cipó, Minas Gerais, Brazil. Acta Bot Bras 29: 24-29.

STRASSBURG BBN ET AL. 2017. Moment of truth for the Cerrado hotspot. Nat Ecol Evol 1: 0099.

STUDLAR SM. 1982. Host specificity of epiphytic bryophytes near mountain lake Virginia. Bryologist 85: 37-50.

SUNDBERG S. 2013. Spore rain in relation to regional sources and beyond. Ecography 36: 364-373.

VANDERPOORTEN A, PAPP B \& GRADSTEIN R. 2010. Sampling of bryophytes. In: Eyman J, Degreef J, Häuser C, Monje, JC, Samyn Y \& Vanden-Spiegel D (Eds), Manual on field recording techniques and protocols for All Taxa Biodiversity Inventories and Monitoring. ABC Taxa 8: 340-354.

VISNADI SR. 2004. Distribuição da brioflora em diferentes fisionomias de cerrado da Reserva Biológica e Estação Experimental de Mogi-Guaçu, SP, Brasil. Acta Bot Bras 18: 965-973.

VISNADI SR \& MONTEIRO R. 1990. Briófitas da cidade de Rio Claro, Estado de São Paulo, Brasil. Hoehnea 17: 71-84.

VISNADI SR \& VITAL DM. 1989. Briófitas rupícolas de um trecho do rio Bethary, Iporanga, estado de São Paulo. Acta Bot Bras 3: 179-183.

VITT DH. 1979. The moss flora of the Auckland Islands, New Zealand, with a consideration of habitats, origins, and adaptations. Can J Bot 57(20): 2226-2263.

WAGNER S, BADER MY \& ZOTZ G. 2014. Physiological Ecology of Tropical Bryophytes. In: Hanson DT \& Rice SK (Eds), Photosynthesis in Bryophytes and Early Land Plants. New York: Springer, p. 269-290.

WALKER MD ET AL. 2006. Plantcommunity responses to experimental warming across the tundra biome. Proc Natl Acad Sci USA 103: 1342-1346.

WATSON W. 1914. Xerophytic Adaptations of Bryophytes in Relation to Habitat. Physiologist 8: 149-190.

WEIBULL H \& RYDIN H. 2005. Bryophyte species richness on boulders: Relationship to area, habitat diversity and canopy tree species. Biol Conserv 122: 71-79. 
WERNER P. 1979. Competition and coexistence of similar species. In: Solbrig OT, Jain S, Johnson GB \& Raven PH (Eds), Topics in Plant Population Biology. Columbia University Press, p. 287-310.

ZAR JH. 2010. Biostatistical Analysis. $5^{\text {th }}$ ed., Pearson Prentice-Hall, Upper Saddle River, New Jersey.

\section{How to cite}

GOMES PWP, MEDEIROS-SARMENTO PS, DOS SANTOS RCP \& TAVARESMARTINS ANC. 2021. Composition and structure of the bryophyte community of Park Savanna in Marajó Island, Pará, Brazil. An Acad Bras Cienc 93: e20190830. DOI 10.1590/0001-3765202120190830.

Manuscript received on July 22, 2019;

accepted for publication on May 11, 2020

\section{PAULO W.P. GOMES ${ }^{1}$}

https://orcid.org/0000-0001-6425-6388

\section{PRISCILA S. DE MEDEIROS-SARMENTO²}

https://orcid.org/0000-0002-5001-9573

\section{RITA DE CÁSSIA P. DOS SANTOS ${ }^{1}$}

https://orcid.org/0000-0001-5008-4095

\author{
ANA CLÁUDIA C. TAVARES-MARTINS ${ }^{1}$ \\ https://orcid.org/0000-0003-4972-036X \\ ${ }^{1}$ Programa de Pós-Graduação em Ciências Ambientais, \\ Universidade do Estado do Pará, Centro de Ciências \\ Naturais e Tecnologia, Travessa Dr. Enéas Pinheiro, \\ 2626, Marco, 66095-015 Belém, PA, Brazil \\ ${ }^{2}$ Instituto Tecnológico Vale, Desenvolvimento Sustentável, Rua \\ Boaventura da Silva, 955, Nazaré, 66055-090 Belém, PA, Brazil
}

Correspondence to: Paulo Weslem Portal Gomes

E-mail:weslemuepa@hotmail.com

\section{Author contributions}

Paulo Weslem Portal Gomes: this paper is the result of his master's dissertation. He participated in the planning of the experimental design of the research and carried out the data collection in the field, as well as in the identification and herbalization of the botanical material. He collaborated in the analysis and interpretation of data and writing of the article. Priscila Sanjuan de Medeiros-Sarmento: she was co-supervisor of the first author's master's degree. She participated in the planning of the experimental design of the research and in the treatment of the statistical analysis of the data, as well as the readings and corrections in the article. Rita de Cássia Pereira dos Santos: Participated in the planning of the experimental design of the research and guidance of data collection in the field. She taught the first author to identify bryophytes, specifically mosses, at the species level. Ana Cláudia Caldeira Tavares-Martins: she was the master's advisor of the first author. She participated in the planning of the experimental design of the research and guidance of data collection in the field. She did several readings and corrections to this paper. She taught the first author to identify bryophytes, specifically hepatic ones, at the species level.

\section{(cc) BY}

